Zagazig Veterinary Journal, CFaculty of Veterinary Medicine, Zagazig University, 44511, Egypt.

Volume 47, Number 1, p. 78-90, March 2019

DOI: $10.21608 / z v j z .2019 .6293 .1016$

\title{
Characterization of Circulating Exosomal MicroRNAs and its Role as Biomarkers for
} Metabolic Syndrome

\author{
Khalifa A. El-Dawy ${ }^{1}$, Haytham A. Ali ${ }^{1,2}$ and Samar A. Abdo ${ }^{\mathbf{1}^{*}}$ \\ ${ }^{1}$ Biochemistry Department, Faculty of Veterinary Medicine, Zagazig University, 44511 Egypt \\ ${ }^{2}$ Biochemistry Department, Faculty of Science, Jeddah University,23443 Saudi Arabia Kingdom
}

Article History: Received: 27/11/2018 Received in revised form: 18/12/2018 Accepted: 12/1/2019

\begin{abstract}
Exosomal microRNAs (EXO-miRNAs) attract major importance as prospective diagnostic biomarkers for metabolic syndrome (MS). The intent of our trials was to characterize the serum exosomes, exosomal miRNA and their target genes to identify those that were altered in relation to the different conditions of metabolic syndrome (Type II diabetes mellitus, high-fat-induced obesity and its related disorders) with different forms of treatment to evaluate their use as diagnostic and treatment biomarkers. Eighty male adult albino rats were used in this experiment, 10 served as normal control group and other 70 divided into 7 different groups; the first received high fat high fructose (HFHF) diet for 4 weeks, second received HFHF diet and confirmed to be diabetic and the other five groups are diabetics and treated for another 4 weeks with Okra extract, Gum Arabic, Dapagliflozin, combination of Dapagliflozin\& okra Extract and combination of Dapagliflozin\& Gum Arabic, respectively.. Our results explained that, the expression levels of miR-122, fatty acid synthase-1 (FAS-1) and Sterol response elementary binding protein-1 (SREBP-1) were significantly higher in the hepatic tissue of metabolic syndrome model groups than that of control and significantly down-regulated after different treatments but still higher than that of control group while carnitine palmitoyltransferase-1(CPT1) was significantly decreased in the same groups. Also the expression levels of miR-31 was significantly higher in adipose tissue of metabolic syndrome model groups than that of control and significantly down-regulated after different treatments but still higher than that of control group while Leptin gene (Ob), Phosphoinositide-3-kinase, class 2, alpha-polypeptide (PIK3C2A) and Peroxisome proliferator-activated receptor- $\gamma$ (PPAR- $\gamma$ ) were significantly decreased in the same groups.It was concluded that exosomal miRNA signatures are parallel with pathological consequences of metabolic syndrome sufferers as well as numerous miRNAs display potential biomarkers for non-invasive diagnosis of the metabolic changes.
\end{abstract}

Keywords: Exosomes, microRNA, Metabolic syndrome, High fat diet and Diabetes mellitus.

\section{Introduction}

Exosomes are the smallest (30-100 nm) extracellular vesicles produced via a wide range of cells such as neurons, reticulocytes, epithelial cells and tumor cells through multivesicular body (MVB) sorting pathway [1] It was considered as cellular waste products [2], but recently it has been demonstrated as a "bioactive vesicles" promoting communication between cells and immune-regulatory processes by shuttling molecules between cells $[1,3]$ The exosomal contents can provoke several changes in receiver cells at transcriptional, post-transcriptional and epigenetic levels $[4,5]$ Exosomes are produced in numerous cases counting type 2 diabetes mellitus from hepatocytes and visceral adipose tissue; it can transport useful proteins and RNA that regulates the metabolic function of equally distant and nearby cells [6].

Metabolic syndrome (MS), Reaven syndrome or syndrome $\mathrm{X}$ was being outlined as a group of interrelated risk factors for cardiovascular diseases (CVD) and diabetes mellitus, leading to approximately1.6-fold increase in mortality [7]. It is a common cause of the development of atherosclerotic vascular disease and type 2 diabetes (T2D) [8, 9]. It

\footnotetext{
*Corresponding author e-mail: (samerahmed289@yahoo.com), Biochemistry Department, Faculty of 78
}

Veterinary Medicine, Zagazig University, 44511 Egypt. 
comprises the most frequently occurring disorder including systemic hypertension, central obesity, insulin resistance, and atherogenic dyslipidemia (specifically hyper triglyceridemia and low levels of bad cholesterol) [10]. One of the mainly up to date thrilling findings was that miRNAs present in exosomes and these exosomal miRNAs can be actively transported into objective cells [11].

MicroRNAs are a set of small non-coding RNAs (19-22 nucleotides) that perform as modulators at the post-transcriptional level of gene expression and regulating lipid metabolism and carbohydrate biosynthesis [12, 13].

MiR-122 has been well-known as a critical monitor of gene expression in the liver, furthermore it represents more than $70 \%$ of liver miRNA [14]. Moreover, it is involved in a number of vital aspects of liver pathophysiology, metabolism of lipid and hepatitis C Virus reproduction [15].

SREBP-1; a key regulator of lipogenesis at transcriptional level, controls homeostasis of cholesterol inside the cells in addition to stimulation of numerous genes implicated in the fatty acid synthesis (FAs), cholesterol and triacylglycerol [16]. Synthesis of FAs is operated by FAS-1 that make use of malonyl$\mathrm{CoA}$ and NADPH to produce palmitic acid [17]. CPT-1 is a key regulatory enzyme of $\beta$ oxidation of FAs in liver along with low level of CPT-1 favor utilization of FAs for triacylglycerol biogenesis and storage [18].

The elevated level of miR-31 can reduce the gene expression of adipogenic markers PPAR $\gamma$, adipocyte protein $2(\mathrm{aP} 2)$ and CCAAT-enhancer-binding protein- $\alpha(\mathrm{C} / \mathrm{EBP} \alpha)$ and the enhancer binding protein that can operate the leptin promoter [19]. PPAR- $\gamma$ that previously described to control adipogenesis as well as lipid metabolism, recently; in a precedent case it was reported that elevated expression of PPAR- $\gamma$ via high fat diet is accountable for heart diseases by up-regulation of many enzymes (D-beta-hydroxybutyrate dehydrogenase, 3-hydroxy-3-methylglutarylCoA synthase 2 and pyruvate dehydrogenase kinase 4) in mitochondria [20]. Leptin is a fully recognized hormone produced from adipose tissue and control both lipid storage and appetite [21]. Phosphatidylinositol3-kinase (PI3K) Class-IA catalytic subunit (PIK3CA) is a main moderator for the signaling of insulin and concerned in several human diseases as diabetes mellitus [22].

Abelmoschus esculentus fruit (Okra) is one of the classical examples of a plant used not only as food but also for its exceptional therapeutic significance due to its several beneficial effects like hypocholesterolemic, hypoglycemic, antimicrobial, antioxidant, anticonstipation, anti-inflammatory, anti-cancer activities [23].

Gum Arabic; a soluble fermentable fiber that proved to have hypoglycemic, antioxidant property as well as superior fat metabolizing effect in preceding studies [24]. It showed the anti-obesity consequence among well adults [25], and blunted weight gain in many trials in animals [26].

Dapagliflozin was the original SGLT2 inhibitor accepted in the EU (April 2012) and revealed an innovative and insulinindependent mechanism of action. Dapagliflozin is a powerful and extremely selective SGLT2 inhibitor with a distinctive chemical formula with a C-glucoside [27].

This work aimed to highlight the role of exosomal miRNAs (miR-122 and miR-31) as potential biomarkers for diagnosis of different metabolic affections including: Type II diabetes, high-fat-induced obesity and its related disorders as well as assessment of involvement of their target genes.

\section{Materials and methods}

\section{Animal selection and housing}

Eighty male adult albino rats weighting at the commencement of the experiment $(150 \pm 15) \mathrm{g}$ were used in this study. The rats were acquired from the Central Animal House of Faculty of Veterinary Medicine; Zagazig University. They were acclimatized for 2 weeks under standard laboratory conditions without any treatments including good aerated room with appropriate temperature, supplied by clean chow and drinking water ad-libitum. The experimental protocol was approved by the ethics committee of Institutional Animal Care and Use, Zagazig University, Zagazig, Egypt (No. ZU-IACUC/2/F/24/2018). 


\section{Experimental design}

After 2 weeks from adaptation, rats were subdivided into 8 groups (ten each). The first one served as a normal control group (G1), the rats were supplied with the typical rat chow in addition to pure water. With each $100 \mathrm{~g}$ food consumed, the animals from this group had a caloric intake of $300 \mathrm{kcal}$. The other 70 rats were fed high fat and high fructose (HFHF) diet (diet rich in lard obtained from $\mathrm{El}$ Basateen Slaughethourse, Egypt) $60 \%$ and $17 \%$ fructose added to the typical rats foodstuff) [28]. The caloric intake would be $800 \mathrm{kcal}$ per $100 \mathrm{~g}$ food, of which $60 \%$ provided by the lard and $17 \%$ by the fructose supplementary to the typical rat foodstuff for one month. After that, the blood glucose level was measured [29], and rats with blood glucose more than $200 \mathrm{mg} / \mathrm{dl}$ were taken as obese-diabetic group whereas that less than $200 \mathrm{mg} / \mathrm{dl}$ considered as obese non-diabetic group. The rats were then subdivided into different groups and received different treatments for 4 weeks as follow: Group 2 (G2): obese non-diabetic didn't take any medication, group 3 (G3): obese-diabetic didn't take any medication. Group $4(\mathrm{G} 4)$ : diabetic and treated with Okra extract $(200 \mathrm{mg} / \mathrm{kg})$ [30], group 5 (G5): diabetic and treated with Gum Arabic powder $(500 \mathrm{mg} / \mathrm{kg})$ [31], group 6 (G6): diabetic and treated with Dapagliflozin powder $(1 \mathrm{mg} / \mathrm{kg})$ [32], group 7 (G7): diabetic and treated with both Okra extract $(200 \mathrm{mg} / \mathrm{kg})$ and Dapagliflozin powder $(1 \mathrm{mg} / \mathrm{kg})$ and group 8 (G8): diabetic and treated with both Gum Arabic powder $(500 \mathrm{mg} / \mathrm{kg})$ and Dapagliflozin powder $(1 \mathrm{mg} / \mathrm{kg})$.

The dose was modified weekly in relation to changes in weight gain to sustain analogous dosage per $\mathrm{kg}$ body weight of rat along the whole time of the study.

\section{Sampling}

After termination of our study, rats were sacrificed via cervical decapitation, blood was gathered and the serum separated by centrifugation for biochemical investigation, exosomal extraction and western blotting. Small parts from liver and adipose tissues were separated rapidly, washed and kept in liquid nitrogen for molecular investigation.
Serum glucose levels were determined using glucose oxidase method by SPINREACT kit (Girona, Spain). Insulin levels in serum were measured by specific ELIZA kit for rat insulin (Billerica, MA, USA) [33], Calorimetrically the following parameters were measured: total lipids (TL) [34], triacylglycerol (TAG) [35], both of Total Cholesterol (TC) and high-density lipoprotein cholesterol (HDL-c) [36] and both Very low density cholesterol (VLDL-c) \& Low-density lipoprotein cholesterol (LDL-c) was estimated by Friedwald formula [37].

\section{Exosomal isolation}

Total exosome was isolated from serum using Exo-Quick kit (Invitrogen ${ }^{\mathrm{TM}}$, USA). Exo-Quick reagent $(63 \mu \mathrm{L})$ was added to $250 \mu \mathrm{L}$ serum supernatant and precipitated overnight at $4^{\circ} \mathrm{C}$. Then samples were centrifuged at $1500 \mathrm{xg}$ for $30 \mathrm{~min}$ at $4^{\circ} \mathrm{C}$, the exosome pellets were suspended in either phosphate buffer saline (PBS) or in the suitable buffer for RNA or protein determination [38].

\section{Characterization of serum exosomes by transmission Electron Microscopy}

The morphology and particle size of the serum exosomes were examined using TEM. A $10 \mu \mathrm{L}$ of exosomes suspension was loaded on an amorphous carbon coated- copper grid. Negative staining was performed by addition of $10 \mu \mathrm{L}$ of neutral $1 \%$ aqueous phosphotungestic acid. The grid was then examined for the exosomes by TEM operating at an accelerating voltage of $80 \mathrm{kV}$ [39].

\section{Western blot of exosomal markers}

Exosomal proteins were isolated and separated on polyacrylamide gels, transferred on PVDF membrane (Life Technologies). The blot was blocked and incubated at $4{ }^{\circ} \mathrm{C}$ overnight with anti-CD63 $(1: 1,000)$ and antiCD9 $(1: 1,000)$ antibodies. HRP-coupled Antia-Tubulin $\quad(1: 1,000) \quad$ (Santa Cruz Biotechnology.Inc.) was added, incubated at room temperature for $1 \mathrm{~h}$. after which washes were repeated and analysis of protein bands was carried out using Image $\mathbf{J}$ software [40]

\section{Molecular analysis}

\section{Biochemical analysis}


Molecular detection of exosomal miR-122 and miR-31

The miRNAs were extracted from isolated exosomes using mirVana PARIS kits (Ambion, Life Technologies, USA) following the manufacturer's instructions. cDNA were synthesized from extracted miRNA using Quanti-Mir RT kit (System Biosciences,USA). Quantitative real-time PCR (qRT-PCR) analysis was conducted on the Step One Plus real time thermal cycler (Applied Biosystems, Life technology, USA) using the 2X Maxima SYBR Green/ROX qPCR Master Mix at a final volume of $30 \mu \mathrm{L}$ according to the manufacturer's instructions (Thermo Scientific, USA). The thermal cycler was programmed to $95^{\circ} \mathrm{C}$ for $1 \mathrm{~min}, 45$ cycles at $\left(95^{\circ} \mathrm{C}\right.$ for $30 \mathrm{sec}, 60^{\circ} \mathrm{C}$ for $40 \mathrm{sec}$, and $72^{\circ} \mathrm{C}$ for $45 \mathrm{sec}$ ), and then a final extension at $72^{\circ} \mathrm{C}$ for $10 \mathrm{~min}$ followed by a melting curve program $\left(55-95^{\circ} \mathrm{C}\right.$ in increasing steps of $0.5^{\circ} \mathrm{C}$ ). $\beta$ actin gene was used as controls to normalize the qRT-PCR. Efficiencies of each reaction were calculated using Livak and Schmittgen method [41]. Unambiguous forward primers for miR-122 and miR-31were listed in Table 1 while a universal reverse primer was supplied by the purchased QuantiMir RT kit. For further confirmation that the sequence of the primer match the template sequence; Similarity were checked with BLAST (Basic Local Alignment Search Tool, www. ncbi.nhm.nih.gov/blast/Blast.cgi) [42].

Molecular detection of CPT-1, SREBP1c, FAS, PI3KC2A Leptin, and PPAR- $\gamma$ genes

Total RNA from hepatic and adipose tissues were extracted using RNeasy Mini Kit (Qiagen GmbH, Düsseldorf, Germany). cDNA synthesis and Real-time PCR were performed for the desired genes as explained above for miRNA using the same kits and the same procedures, and the primer used listed in Table 1.

Table 1: Target genes and oligonucleotide primer sequences used for real time PCR in this study

\begin{tabular}{|c|c|}
\hline Target Gene & Primer sequence ('5 ------ 3 ) \\
\hline miR-122 & IGAGTGTGACAATGGTGTTTG \\
\hline miR-31 & 3GCAAGATGCTGGCATAGCTG \\
\hline$m i R-16$ & JGTAGCAGCACGTAAATATTGGCGA \\
\hline \multirow{2}{*}{ CPT1 } & CCAGGCAAAGAGACAGACTTG \\
\hline & ЭCCAAACCTTAGAGAAGCGA \\
\hline \multirow{2}{*}{ SREBP1c } & GGAGCCATGGATTGCACATT \\
\hline & AGGAAGGCTTCCAGAGAGGA \\
\hline \multirow{2}{*}{ Leptin } & GACATTTCACACACGCAGTC \\
\hline & JAGGAGGTCTCGCAGGTT \\
\hline \multirow{2}{*}{ PPAR- $\gamma$} & GCCAAGAACATCCCCAACTTC \\
\hline & ICAAAGATGGCCTCATGCA \\
\hline \multirow{2}{*}{ FAS } & TGTCAACCGTGTCAGCCTG \\
\hline & ГGGATGATGTTGATGATAGAC \\
\hline \multirow{2}{*}{ PIK3C2A } & ГCCCGTAGCGTGAGCCAG \\
\hline & ГCTGAGCCATGTCCACAAGAG \\
\hline \multirow{2}{*}{$\beta$-actin } & \AGCAATGCTGTCACCTTCCC \\
\hline & АAGTCССТCACССТСССАAAAG \\
\hline
\end{tabular}

The house keeping genes miR-16 for miRNAs and $\beta$-actin for its related genes were used to calculate the relative gene expression or fold change in target genes using Livak and Schmittgen method [41]. 
Our results were articulated as means \pm S.E. The statistical significance was determined by one-way analysis of variance (ANOVA) using SPSS, 22 software, 2013 and the individual comparisons were calculated by Duncan's multiple range test (DMRT). Values were considered statistically significant when $p<0.05$.

\section{Results}

\section{Effect of HFHF diet feeding on biochemical parameters of adult male rats in serum}

The results illustrated in Table 2 showed that feeding HFHF diet resulted in marked increase in serum glucose, lipid profile that represented in increase in total lipids, TAG, TC, LDL-c and VLDL-c in MS groups and these elevated level were lowered following different treatments (Okra Extract, Gum Arabic, Dapagliflozin, Okra extract with Dapagliflozin and Gum Arabic with Dapagliflozin) while there were a significant decrease in the serum levels of both insulin and HDL-c that may predispose to coronary heart disease.

\section{Characterization and labeling serum exosomes}

Examination of retained pellets by TEM showed the presence of small vesicles with regular breadth ranged from 10 to $100 \mathrm{~nm}$ in the extracted rat sera (Figure 1) by exosome isolation kit. Western blot results emphasized the existence of CD63 and CD9 that previously considered main exosomal markers (Figure 2).

Table 2: Effect of HFHF diet feeding on biochemical parameters of adult male rats in serum

\begin{tabular}{|c|c|c|c|c|c|c|c|c|c|}
\hline Group & G1 & G2 & G3 & G4 & G5 & G6 & G7 & G8 & $\begin{array}{c}P \\
\text { Value }\end{array}$ \\
\hline $\begin{array}{l}\text { Blood Glucose } \\
(\mathrm{mmol} / \mathrm{L})\end{array}$ & $\begin{array}{c}5.06 \\
\pm 0.35^{\mathrm{f}}\end{array}$ & $\begin{array}{c}5 \\
\pm 0.34^{\mathrm{f}}\end{array}$ & $\begin{array}{c}19.57 \\
\pm 0.35^{\mathrm{a}}\end{array}$ & $\begin{array}{r}13.86 \\
\pm 0.51^{\mathrm{b}}\end{array}$ & $\begin{array}{l}11.83 \\
\pm 0.15^{\mathrm{c}}\end{array}$ & $\begin{array}{l}10.28 \\
\pm 0.33^{\mathrm{d}}\end{array}$ & $\begin{array}{c}10.84 \\
\pm 0.27^{\mathrm{d}}\end{array}$ & $\begin{array}{c}7.01 \\
\pm 0.35^{\mathrm{e}}\end{array}$ & .00 \\
\hline $\begin{array}{l}\text { Serum } \\
\text { insulin }(\mu I U / m l)\end{array}$ & $\begin{array}{l}12.22 \\
\pm 2.56^{\mathrm{a}}\end{array}$ & $\begin{array}{c}5.37 \\
\pm 1.13^{\mathrm{bc}}\end{array}$ & $\begin{array}{c}3.31 \\
\pm 1.40^{\mathrm{c}}\end{array}$ & $\begin{array}{c}3.83 \\
\pm 1.21^{\mathrm{c}}\end{array}$ & $\begin{array}{r}4.21 \\
\pm 1.60^{\mathrm{bc}}\end{array}$ & $\begin{array}{c}6.08 \\
\pm 1.88^{\mathrm{bc}}\end{array}$ & $\begin{array}{c}8.17 \\
\pm .57^{\mathrm{abc}}\end{array}$ & $\begin{aligned} & 9.17 \\
\pm & 1.50^{\mathrm{ab}}\end{aligned}$ & 0.00 \\
\hline $\begin{array}{l}\text { Total Lipids } \\
\text { (g/L) }\end{array}$ & $\begin{array}{c}5.06 \\
\pm 0.09^{\mathrm{g}}\end{array}$ & & $\begin{array}{l}11.12 \\
\pm 0.06^{\mathrm{b}}\end{array}$ & $\begin{array}{l}9.01 \\
\pm 0.06^{\mathrm{c}}\end{array}$ & $\begin{array}{c}7.01 \\
\pm 0.07^{\mathrm{d}}\end{array}$ & $\begin{array}{c}5.95 \\
\pm 0.03^{\mathrm{e}}\end{array}$ & $\begin{array}{c}5.56 \\
\pm 0.07^{\mathrm{f}}\end{array}$ & $\begin{array}{c}5.06 \\
\pm 0.04^{\mathrm{g}}\end{array}$ & 0.00 \\
\hline TAG(mmol/L) & $\begin{array}{c}0.84 \\
\pm 0.01^{\mathrm{e}}\end{array}$ & $\begin{array}{c}3.82 \\
\pm 0.05^{\mathrm{e}}\end{array}$ & $\begin{array}{c}3.34 \\
\pm 0.02^{\mathrm{a}}\end{array}$ & $\begin{array}{c}2.81 \\
\pm 0.04^{\mathrm{b}}\end{array}$ & $\begin{array}{c}1.96 \\
\pm 0.03^{\mathrm{c}}\end{array}$ & $\begin{array}{c}0.97 \\
\pm 0.03^{\mathrm{d}}\end{array}$ & $\begin{array}{c}0.94 \\
\pm 0.03^{\mathrm{d}}\end{array}$ & $\begin{array}{c}0.81 \\
\pm 0.01^{\mathrm{e}}\end{array}$ & 0.00 \\
\hline TC (mmol/L) & $\begin{array}{c}3.66 \\
\pm 0.04^{\mathrm{d}}\end{array}$ & $\begin{array}{c}7.72 \\
\pm 0.03\end{array}$ & $\begin{array}{c}8.15 \\
\pm 0.08^{\mathrm{a}}\end{array}$ & $\begin{array}{c}7.51 \\
\pm 0.03^{b}\end{array}$ & $\begin{array}{c}5.25 \\
\pm 0.08^{\mathrm{c}}\end{array}$ & $\begin{array}{c}5.21 \\
\pm 0.08^{\mathrm{c}}\end{array}$ & $\begin{array}{c}5.22 \\
\pm 0.06^{\mathrm{c}}\end{array}$ & $\begin{array}{c}5.08 \\
\pm 0.08^{\mathrm{c}}\end{array}$ & 0.00 \\
\hline LDL-c(mmol/L) & $\begin{array}{c}1.21 \\
\pm 0.08^{\mathrm{e}}\end{array}$ & $\begin{array}{c}5.70 \\
\pm 0.06^{\mathrm{b}}\end{array}$ & $\begin{array}{c}6.15 \\
\pm 0.06^{\mathrm{a}}\end{array}$ & $\begin{array}{c}5.51 \\
\pm 0.04^{\mathrm{b}}\end{array}$ & $\begin{array}{c}3.22 \\
\pm 0.10^{\mathrm{cd}}\end{array}$ & $\begin{array}{c}3.24 \\
\pm 0.08^{\mathrm{cd}}\end{array}$ & $\begin{array}{c}3.45 \\
\pm 0.01^{\mathrm{c}}\end{array}$ & $\begin{array}{c}3.13 \\
\pm 0.07^{\mathrm{d}}\end{array}$ & 0.00 \\
\hline HDL-c(mmol/L) & $\begin{array}{c}2.05 \\
\pm 0.12^{\mathrm{a}}\end{array}$ & $\begin{array}{c}0.51 \\
\pm 0.03^{\mathrm{f}}\end{array}$ & $\begin{array}{c}0.47 \\
\pm 0.02^{\text {f }}\end{array}$ & $\begin{array}{c}0.97 \\
\pm 0.03^{\mathrm{e}}\end{array}$ & $\begin{array}{c}1.12 \\
\pm .001^{\mathrm{de}}\end{array}$ & $\begin{aligned} & 1.52 \\
& \pm 0.02^{\mathrm{bc}}\end{aligned}$ & $\begin{aligned} & 1.32 \\
& \pm 0.01^{\mathrm{cd}}\end{aligned}$ & $\begin{array}{c}1.56 \\
\pm 0.02^{\mathrm{b}}\end{array}$ & 0.00 \\
\hline VLDLc(mmol/L & $38 \pm 0.01^{\mathrm{e}}$ & $\begin{array}{c}1.50 \\
\pm 0.02^{\mathrm{a}}\end{array}$ & $\begin{array}{c}1.53 \\
\pm 0.01^{\mathrm{a}}\end{array}$ & $0.99 \pm 0.01^{\mathrm{b}}$ & $\begin{array}{c}0.89 \\
\pm 0.01^{\mathrm{c}}\end{array}$ & $\begin{array}{c}0.44 \\
\pm 0.01^{\mathrm{d}}\end{array}$ & $\begin{array}{c}0.43 \\
\pm 0.01^{\mathrm{d}}\end{array}$ & $\begin{array}{c}0.37 \\
\pm 0.001^{\mathrm{e}}\end{array}$ & 0.00 \\
\hline
\end{tabular}

TAG: triacylglycerol, TC: Total Cholesterol, LDL-c: Low-density lipoprotein cholesterol, HDL-c: high density lipoprotein cholesterol and VLDL-c: Very low density cholesterol. Means \pm SE in the same row and carrying different superscripts are significantly different at $p<0.05$. 


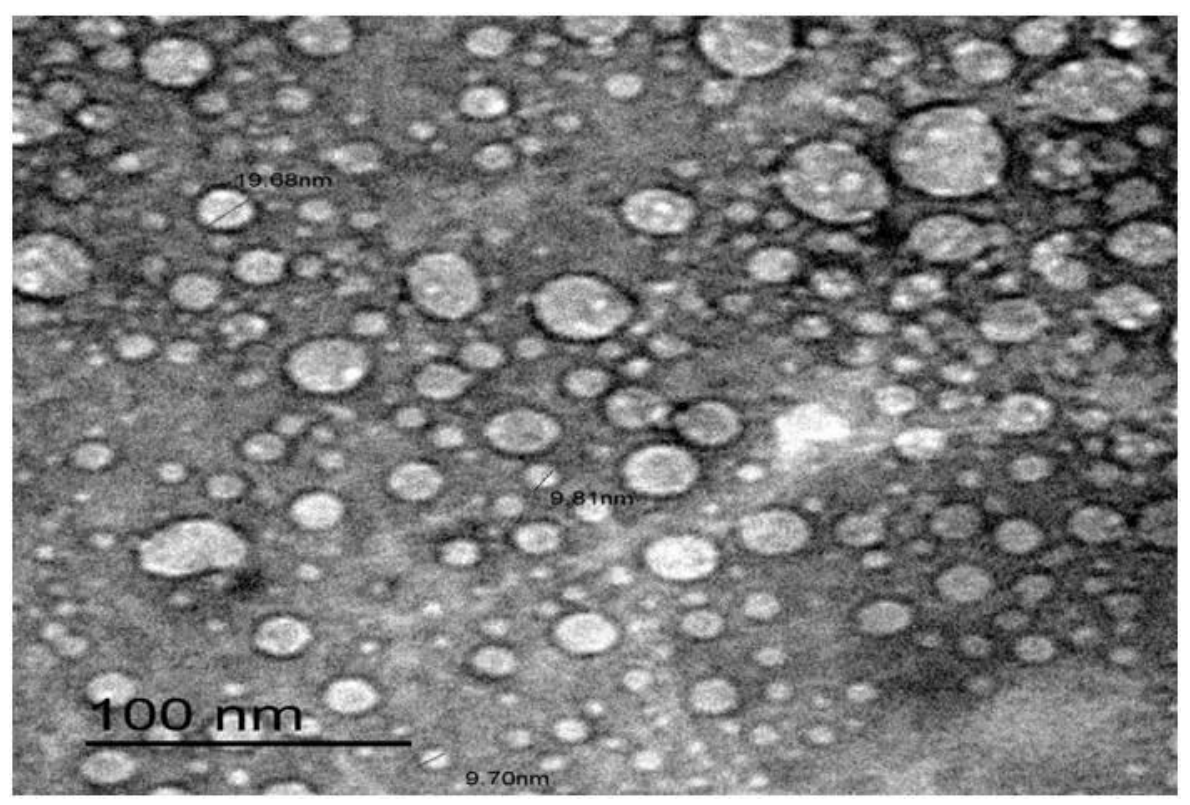

Figure 1: Transmission electron microscopic examination shows small nanovesicles $(10-100 \mathrm{~nm})$ in the sample isolated from rat sera by exosome isolation kit. The scale bar represents $100 \mathrm{~nm}$.
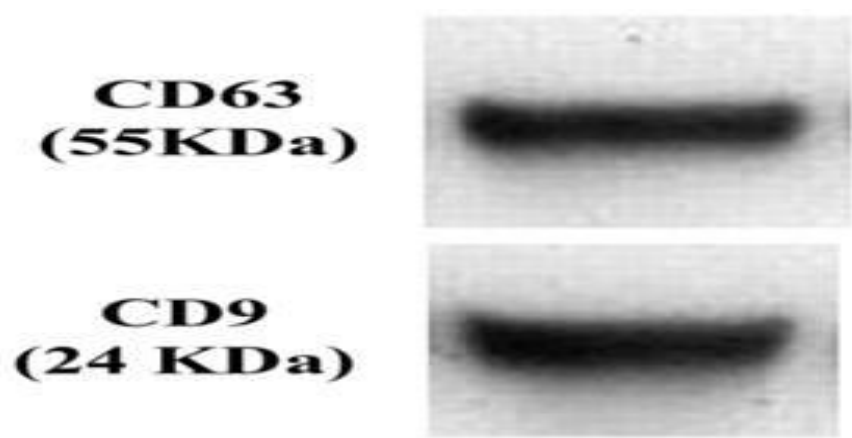

Figure 2: Western blot analysis of the exosomes shows presence of CD63 and CD9 proteins in the serum exosomes of rats. KDa; kilo Dalton.

\section{Transcription levels}

The expression of miR-122 and miR31 were significantly up-regulated in the exosomes extracted from the serum of obesediabetic rats $(\mathrm{G} 3)$ and obese-non diabetic $(\mathrm{G} 2)$ compared with other treatments (Figure 3 a,b). Okra Extract (G4) was significantly enhanced the transcription of miR-122 and miR-31 compared with other treatments (Figure 3a,b), while Gum Arabic +Dapagliflozin (G8) treatments showed the lowest expression of miR-122 and miR-31. 

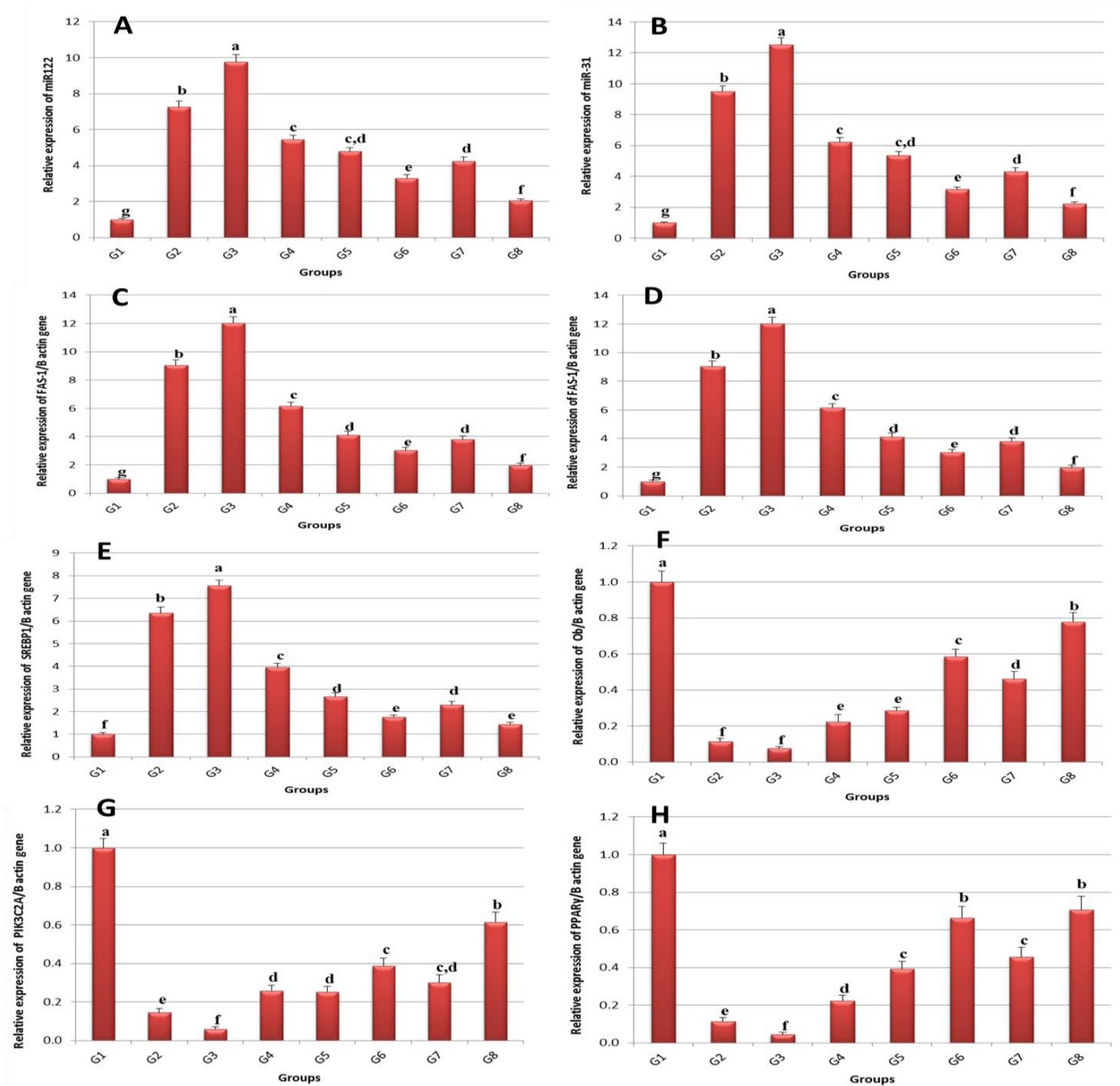

Figure 3: Graphical presentation of real-time quantitative PCR analysis of the expression of miR-122 (A) and miR-31 (B) in exosomes extracted from serum of diabetic rats, CPT-1 (C), FAS (D), SREBP1c (E) as miR-122 targets in hepatic tissue and Leptin/obese (ob) (F), PIK3C2 (G) and PPAR- $\gamma(\mathrm{H})$ genes as targets for miR-31 in adipose tissue of normal control (G1), obese-non diabetic (G2) and obese-diabetic rats (G3) and treated rats for 4 weeks with Okra extract (G4), Gum Arabic(G5), Dapagliflozin (G6), combination of Dapagliflozin\& okra Extract(G7) and combination of Dapagliflozin\& Gum Arabic (G8). Columns carrying different superscripts are significantly different at $p<0.05$. Bars represent means \pm S.E.

The transcript level of hepatic targets of miR-122 of CPT1 gene was significantly inhibited for all treatments compared with the normal control group (G1) (Figure 3c). Obese-diabetic rats (G3) showed the lowest transcript level compared with other treatments, however, the expressions of CPT1 were clearly enhanced with Gum Arabic + Dapagliflozin (G8) followed by treatments of G6 and G7(Figure 3c).
The expressions of FAS and SREBP1c genes were highly transcript with obesediabetic rats (G3) compared with all treatments (Figure $3 \mathrm{~d}, \mathrm{e}$ ). As well as the transcription of FAS and SREBP1c genes were highly accumulated with obese-nondiabetic rats (G2) treatments. In general, the transcription of FAS was up-regulated for treatments of Okra extract (G4), Gum Arabic (G5), Dapagliflozin (G6), Okra extract+ Dapagliflozin (G7), and 
Gum Arabic + Dapagliflozin (G8) (Figure 3d,e).

The transcription levels for adipose tissue targets of miR-31 revealed a significant downregulation of leptin /obese $(\mathrm{Ob}), \mathrm{PIK} 3 \mathrm{C} 2$ and PPAR- $\gamma$ genes (Figure $3 \mathrm{f}, \mathrm{g}, \mathrm{h}$ ) for obese-non diabetic rats (G2) and obese-diabetic rats (G3) compared with other treatments. The expression of these three genes was slightly enhanced with treatments of Okra extract (G4), Gum Arabic (G5). While the expression of the three genes was clearly enhanced with treatment Gum Arabic + Dapagliflozin (G8) followed by treatments of G6 and G7 (Figure 3f, g, h).

\section{Discussion}

The finding that exosomes are contained miRNAs has resulted in a great interest in these nanovesicles as prospective vehicles for miRNA transfer between cells in addition to being a provenance for diagnostic biomarkers as extracellular miRNA. Recently, exosomal miRNAs have considered as ultimate prospective biomarkers since they are protected from various ribo-nucleases that can destruct the circulating miRNAs in extracellular fluid with extreme tissue specificity [43, 44], Furthermore, miRNAs; the short RNAs can direct protein-coding genes and affect their expression in different tissues.

The intent of the current study was to clarify the character of specific serum exosomal miRNAs as biomarkers reflecting the metabolic state during metabolic syndrome. At the same time detecting the profile of some related gene expression in the same case.The state of metabolic syndrome was confirmed through the biochemical investigation of serum glucose, serum insulin and lipid profile. Feeding HFHF diet given rise to a significant increase in the serum levels of blood glucose, total lipids, total cholesterol, VLDL-c, LDL-c and TAG with a significant reduction in both serum insulin and HDL-c which confirms the state of T2DM. Gancheva et al. [29] and López et al. [45] reported that, feeding HFHF diet for 12 weeks resulted in induction of metabolic syndrome and with elevated serum glucose and lipid profile and a reduction in serum insulin and HDL-c.
To verify the isolation of the exosomes from the serum, TEM results, were examined from the Exo-Quick isolated sera revealed round vesicles of $10-100 \mathrm{~nm}$ in diameters. Similar results were reported by Dejima et al. [46]. In addition, detection of exosomal protein; both CD9 and CD63 the well-known exosomal markers, and their expression were analyzed by Western blotting. Recent studies have detected more and more exosome associated miRNAs associated with different kinds of chronic diseases, especially metabolic disorders such as diabetes mellitus, fatty liver, obesity, and atherosclerosis [47].

The effect that exosomal miRNAs may have on the functioning of several endocrine tissues and organs is complicated so we focused on liver and adipose tissue as main organs implicated in metabolic disorders.

Hepatic tissue has a central role in maintaining both glucose and lipid level of the blood in addition to many disorders in liver function influence lipid and glucose balance and haemostasis. Moreover, impairment of liver signaling and metabolism can grounds for predisposition to insulin-independent diabetes [48].

The miR-122 was verified to be primarily synthesized by liver cells, and takes part in the metabolism of lipids and cholesterol [49]. Many years later on another study by Pirola $e t$ al. [50] the main source of miR-122 detected in the serum of nonalcoholic fatty liver disease (NAFLD) patients is in the form of exosomes. In the area of lipid metabolism, miR-122, miR-33 and SREBP-2 may regulate the cell cholesterol level and have an imperative responsibility in the transportation of free cholesterol and synthesis of high-density lipoprotein [51]. Moreover, exosomes were separated from high fat-diet NAFLD mice models and found that the proteins carried by exosomes were different from those in control groups, and those levels of miR-122 and miR192 had increased in the blood indicating that these miRNAs might be prospective markers for reflecting the development of fatty liver disease [51]. In this study; exosomal miR-122 was up-regulated in the sera of rats from metabolic syndrome (MS) model groups (G2 and G3) with up-regulation of its targets in 
liver (FAS-1 and SREBP-1c) as previously reported [52]. While, CPT-1 was downregulated in MS groups as compared to the control; then elevated with different treatment with highest level in the group treated with Okra+ Gum Arabic+ Dapagliflozin suggesting improved fatty acids oxidation to be no longer available for triacylglycerol synthesis [53].

Visceral fat, the store house of TAG, chiefly implicated in regulation of energy homeostasis [54], irregular fat deposition in obese subject mainly central obesity predispose to the risk of affection with serious disorders for instance MS, type 2 diabetes (T2D), atherosclerosis, along with cancer formation [55].

In the present study, the exosomal miR31 isolated from sera of MS groups exhibited elevated expression as compared to control group, with down regulation of its targets in adipose tissues where leptin, PI3KC2A and PPAR- $\gamma$ were down-regulated in both obesenon diabetic and obese-diabetic rats when compared to control group, with elevated levels after treatment by Okra extract, Gum Arabic, Dapagliflozin and their combinations with the highest level in group treated with both Gum Arabic and Dapagliflozin; confirming the antiadipogenic role of miR-31. This was in concordance with the consequences of a previous study reported that miR-31 level is indirectly associated with the stage of adipogenic-differentiation as well as its influential anti-adipogenic function through the obvious down-regulation of the adipogenic genes[56].

\section{Conclusion}

It is concluded that serum exosomal miR-122 and miR-31 could be potential biomarkers to predict liver and adipose tissue state in case of metabolic syndrome affection.

\section{Conflict of Interest}

The authors have no conflict of interest to declare.

\section{References}

[1] Thery, C.; Ostrowski, M. and Segura, E. (2009): Membrane vesicles as conveyors of immune responses. Nat Rev Immunol, 9(8), 581-593.
[2] Théry, C. (2011): Exosomes: Secreted vesicles and intercellular communications. F1000 biology reports, 3, 15.

[3] Pegtel, D. M.; Cosmopoulos, K.; ThorleyLawson, D. A.; van Eijndhoven, M. A.; Hopmans, E. S.; Lindenberg, J. L.; de Gruijl, T.D.; Würdinger, T. and Middeldorp, J. M. (2010): Functional delivery of viral miRNAs via exosomes. ProcNatlAcadSci U S A., 107(14), 63286333.

[4] Bobrie, A.; Colombo, M.; Raposo, G. and Théry, C. (2011): Exosome Secretion: Molecular Mechanisms and Roles in Immune Responses. Traffic, 12(12), 16591668.

[5] Marques-Garcia, F. and Isidoro-Garcia, M. (2016): Protocols for Exosome Isolation and RNA Profiling. Methods MolBiol, 1434, 153-167. doi: 10.1007/978-1-49393652-6_11

[6] Guescini, M.; Guidolin, D.; Vallorani, L.; Casadei, L.; Gioacchini, A.; Tibollo, P.; Agnati, L. and Stocchi, V. (2010): C2C12 myoblasts release micro-vesicles containing mtDNA and proteins involved in signal transduction. Exp Cell Res, 316(12), 1977-1984.

[7] Harris, M. (2013): The metabolic syndrome. AustFam Physician, 42, 524527.

[8] Haffner, S. M.; Valdez, R. A.; Hazuda, H. P.; Mitchell, B. D.; Morales, P. A. and Stern, M. P. (1992): Prospective Analysis of The Insulin-Resistance Syndrome (Syndrome X). Diabetes, 41(6), 715-722.

[9] Isomaa, B.; Almgren, P.; Tuomi, T.; Forsén, B.; Lahti, K.; Nissén, M.; Taskinen, M.R. and Groop, L. (2001): Cardiovascular Morbidity and Mortality Associated With the Metabolic Syndrome. Diabetes care, 24(4), 683-689.

[10] McCracken, E.; Monaghan, M. and Sreenivasan, S. (2018): Pathophysiology of the metabolic syndrome. ClinDermatol, 36(1), 14-20.

[11] Montecalvo, A., Larregina, A. T., Shufesky, W. J., Stolz, D. B., Sullivan, M. L., Karlsson, J. M.; Baty, 
C.J.; Gibson， G.A.; Erdos， G.; Wang, Z.; Milosevic, J.; Tkacheva, O.A.; Divito, S.J.; Jordan, R.; LyonsWeiler, J.; Watkins, S.C. and Morelli, A. E. (2012): Mechanism of transfer of functional microRNAs between mouse dendritic cells via exosomes. Blood, 119(3), 756-766.

[12] Karolina, D. S.; Tavintharan, S.; Armugam, A.; Sepramaniam, S.; Pek, S. L. T.; Wong, M. T.; Lim, S.C.; Sum, C.F. and Jeyaseelan, K. (2012): Circulating miRNA profiles in patients with metabolic syndrome. J ClinEndocrinolMetab, 97(12), E2271E2276.

[13] Ye, Q.; Zhao, X.; Xu, K.; Li, Q.; Cheng, J.; Gao, Y.; Du, J. ; Shi, H. and Zhou, L. (2013): Polymorphisms in lipid metabolism related miRNA binding sites and risk of metabolic syndrome. Gene, 528(2), 132-138.

[14] Lagos-Quintana, M.; Rauhut, R.; Yalcin, A.; Meyer, J.; Lendeckel, W. and Tuschl, T. (2002): Identification of tissuespecific microRNAs from mouse. Curr Biol., 12(9), 735-739.

[15] Oliveira, K. G.; Malta, F. M.; Nastri, A. C.; Widman, A.; Faria, P. L.; Santana, R. A.; Alves, V.A. ; Carrilho, F.J. and Pinho, J. R. (2016): Increased hepatic expression of miRNA-122 in patients infected with HCV genotype 3. Med MicrobiolImmunol, 205(2), 111-117.

[16] Horton, J.; Goldstein, J. and Brown, M. (2002): SREBPs: transcriptional mediators of lipid homeostasis. Cold Spring HarbSymp Quant Biol.67:491498.

[17] Rudolph, M. C.; Maluf, N. K.; Wellberg, E. A.; Johnson, C. A.; Murphy, R. C. and Anderson, S. M. (2012): Mammalian fatty acid synthase activity from crude tissue lysates tracing 13C-labeled substrates using gas chromatographymass spectrometry. Anal Biochem, 428(2), 158-166.

[18] Abu-Elheiga, L.; Matzuk, M. M.; AboHashema, K. A. and Wakil, S. J. (2001): Continuous fatty acid oxidation and reduced fat storage in mice lacking acetyl-CoA carboxylase 2. Science, 291(5513), 2613-2616.

[19] Sun, F.; Wang, J.; Pan, Q.; Yu, Y.; Zhang, Y.; Wan, Y.; Wang, J.; Li, X. and Hong, A. (2009): Characterization of function and regulation of miR-24-1 and miR-31. BiochemBiophys Res Commun, 380(3), 660-665.

[20] Sikder, K.; Shukla, S. K.; Patel, N.; Singh, H. and Rafiq, K. (2018): High Fat Diet Upregulates Fatty Acid Oxidation and Ketogenesis via Intervention of PPAR-gamma. Cell PhysiolBiochem, 48(3), 1317-1331.

[21] Friedman, J. M. and Halaas, J. L. (1998): Leptin and the regulation of body weight in mammals. Nature, 395(6704), 763.

[22] Cantley, L. C. (2002): The phosphoinositide 3-kinase pathway. Science, 296(5573), 1655-1657.

[23] Viuda-Martos, M.; López-Marcos, M. C.; Fernández-López, J.; Sendra, E.; López-Vargas, J. H. and Pérez-Álvarez, J. A. (2010): Role of Fiber in Cardiovascular Diseases: A Review. Comprehensive Reviews in Food Science and Food Safety, 9(2), 240-258.

[24] Ali, B. H.; Ziada, A. and Blunden, G. (2009): Biological effects of gum arabic: a review of some recent research. Food ChemToxicol, 47(1), 1-8.

[25] Babiker, R.; Elmusharaf, K.; Keogh, M. B. and Saeed, A. M. (2018): Effect of Gum Arabic (Acacia Senegal) supplementation on visceral adiposity index (VAI) and blood pressure in patients with type 2 diabetes mellitus as indicators of cardiovascular disease (CVD): a randomized and placebocontrolled clinical trial. Lipids in health and disease, 17(1), 56-56.

[26] Ahmed, A. A.; Musa, H. H.; Fedail, J. S.; Sifaldin, A. Z. and Musa, T. H. (2015): Gum arabic decreased visceral adipose tissue associated with downregulation of $11 \beta$-hydroxysteroid dehydrogenase type $\mathrm{I}$ in liver and muscle of mice. Bioactive 
Carbohydrates and Dietary Fibre, 6(1), 31-36.

[27] Aoki, N.; Jin-No, S.; Nakagawa, Y.; Asai, N.; Arakawa, E.; Tamura, N.; Tamura, T. and Matsuda, T. (2007): Identification and characterization of microvesicles secreted by 3T3-L1 adipocytes: redox-and hormonedependent induction of milk fat globuleepidermal growth factor 8-associated microvesicles. Endocrinology, 148(8), 3850-3862.

[28] de Castro, U. G. M.; Silva, M. E.; de Lima, W. G.; Campagnole-Santos, M. J. and Alzamora, A. C. (2013): Agedependent effect of high-fructose and high-fat diets on lipid metabolism and lipid accumulation in liver and kidney of rats. Lipids in health and disease, 12(1), 136.

[29] Gancheva, S.; Zhelyazkova-Savova, M.; Galunska, B. and Chervenkov, T. (2015): Experimental models of metabolic syndrome in rats. Scripta Scientifica Medica; 47, (2). 14-21.

[30] Thanakosai, W. and Phuwapraisirisan, P. (2013): First identification of $\alpha$ glucosidase inhibitors from okra (Abelmoschusesculentus) seeds. Natural product communications, 8(8), 10851088.

[31] Kumar Bhateja, P. and Singh, R. (2014): Antidiabetic activity of Acacia tortilis (Forsk.) Hayne ssp. raddiana polysaccharide on streptozotocinnicotinamide induced diabetic rats. BioMed research international, 1-9.

[32] Tatarkiewicz, K.; Polizzi, C.; Villescaz, C.; D'Souza, L. J.; Wang, Y.; Janssen, S. and Parkes, D. G. (2014): Combined antidiabetic benefits of exenatide and dapagliflozin in diabetic mice. Diabetes, Obesity and Metabolism, 16(4), 376-380.

[33] Wang, D.; Zhu, W.; Li, J.; An, C. and Wang, Z. (2013): Serum concentrations of fibroblast growth factors 19 and 21 in women with gestational diabetes mellitus: association with insulin resistance, adiponectin, and polycystic ovary syndrome history. PLOS ONE, 8(11), e81190.

[34] Zoungas, S.; Chalmers, J.; Neal, B.; Billot, L.; Li, Q.; Hirakawa, Y.; Arima, H.; Monaghan, H.; Joshi, R.; Colagiuri, S.; Cooper, M. E. ; Glasziou, P.; Grobbee, D.; Hamet, P.; Harrap, S.; Heller, S.; Lisheng, L.; Mancia, G.; Marre, M.; Matthews, D. R.; Mogensen, $\quad$ C. $\quad$ E.; Perkovic, V.; Poulter, N.; Rodgers, A.; Williams, B. ; MacMahon, S.; Patel, A. and Woodward, M. (2014): Follow-up of blood-pressure lowering and glucose control in type 2 diabetes. N Engl J Med, 371(15), 1392-1406.

[35] Bucolo, G. and David, H. (1973): Quantitative determination of serum triglycerides by the use of enzymes. Clinic Chem, 19(5), 476-482.

[36] Young, D. S., and Friedman, R. B. (2001). Effects of disease on clinical laboratory tests. 2. Listing by disease. AACC-Press.

[37] Friedewald, W. T.; Levy, R. I. and Fredrickson, D. S. (1972): Estimation of the concentration of Low-Density Lipoprotein Cholesterol in plasma, without use of the preparative ultracentrifuge. Clinic Chem, 18(6), 499502.

[38] Pieters, B. C. H.; Arntz, O. J.; Bennink, M. B.; Broeren, M. G. A.; van Caam, A. P. M.; Koenders, M. I.; van Lent, P. L.; van den Berg, W. B. ; de Vries, M.; van der Kraan, P.M. and van de Loo, F. A. J. (2015): Commercial cow milk contains physically stable extracellular vesicles expressing immunoregulatory TGF- $\beta$. PLOS ONE, 10(3), e0121123. doi: 10.1371/journal.pone.0121123

[39] Wu, Y.; Deng, W. and Klinke, D. J. 2nd. (2015): Exosomes: improved methods to characterize their morphology, RNA content, and surface protein biomarkers. The Analyst, 140(19), 6631-6642. doi: $10.1039 / \mathrm{c} 5 \mathrm{an} 00688 \mathrm{k}$

[40] Vallabhajosyula, P.; Korutla, L.; Habertheuer, A.; Yu, M.; Rostami, S.; Yuan, C. X.; Reddy, S.; Liu, 
C.; Korutla, V.; Koeberlein, B.; TrofeClark, J.; Rickels, M. R. and Naji A.(2017): Tissue-specific exosome biomarkers for noninvasively monitoring immunologic rejection of transplanted tissue. J Clinic Invest, 127(4), 13751391.

[41] Livak, K. J. and Schmittgen, T. D. (2001): Analysis of relative gene expression data using real-time quantitative $\mathrm{PCR}$ and the $2-\Delta \Delta \mathrm{CT}$ method. Methods, 25(4), 402-408.

[42] Ye, J.; Coulouris, G.; Zaretskaya, I.; Cutcutache, I.; Rozen, S. and Madden, T. L. (2012): Primer-BLAST: a tool to design target-specific primers for polymerase chain reaction. BMC bioinformatics, 13(1), 134.

[43] Cheng, L.; Sharples, R. A.; Scicluna, B. J. and Hill, A. F. (2014): Exosomes provide a protective and enriched source of miRNA for biomarker profiling compared to intracellular and cell-free blood. J Extracell Vesicles, 3, 10.3402/jev.v3403.23743.

[44] Yang, Q.; Diamond, M. P. and AlHendy, A. (2016): The emerging role of extracellular vesicle-derived miRNAs: implication in cancer progression and stem cell related diseases. J ClinEpigenet, 2(1): 13.

[45] López, M.; Ríos-Silva, M.; Huerta, M.; Cárdenas, Y.; Bricio-Barrios, J. A.; DíazReval, M. I.; Urzúa, Z.; Huerta-Trujillo, M.; López-Quezada, K. and Trujillo, X. (2018): Effects of Moringaoleifera leaf powder on metabolic syndrome induced in male Wistar rats: a preliminary study. J Int Med Res, 46(8), 3327-3336.

[46] Dejima, H.: Iinuma, H.: Kanaoka, R.: Matsutani, N. and Kawamura, M. (2017). Exosomal microRNA in plasma as a non invasive biomarker for the recurrence of non-small cell lung cancer. Oncology letters, 13(3), 1256-1263.

[47] Yao, Z. Y.; Chen, W. B.; Shao, S. S.; Ma, S. Z.; Yang, C. B.; Li, M. Z.; Zhao, J.J. and Gao, L. (2018): Role of exosome-associated microRNA in diagnostic and therapeutic applications to metabolic disorders. J Zhejiang UnivSci B, 19(3), 183-198.

[48] Mueting, D. (1962): Role of the liver in protein metabolism and detoxicating function in prediabetes and diabetes mellitus. KlinischeWochenschrift, 40, 105-107.

[49] Lewis, A. P. and Jopling, C. L. (2010): Regulation and biological function of the liver-specific miR-122. BiochemSoc Trans, 38(6), 1553-1557.

[50] Pirola, C. J.; Fernandez Gianotti, T.; Castano, G. O.; Mallardi, P.; San Martino, J.; Mora Gonzalez Lopez Ledesma, M.; Flichman, D.; Mirshahi, F.; Sanyal, A. J. and Sookoian, S. (2015): Circulating microRNA signature in nonalcoholic fatty liver disease: from serum non-coding RNAs to liver histology and disease pathogenesis. Gut, 64(5), 800812.

[51] Najafi-Shoushtari, S. H.; Kristo, F.; Li, Y.; Shioda, T.; Cohen, D. E.; Gerszten, R. E. and Naar, A. M. (2010): MicroRNA-33 and the SREBP host genes cooperate to control cholesterol homeostasis. Science, 328(5985), 15661569.

[52] Povero, D.; Eguchi, A.; Li, H.; Johnson, C. D.; Papouchado, B. G.; Wree, A.; Messer, K. and Feldstein, A. E. (2014): Circulating extracellular vesicles with specific proteome and liver microRNAs are potential biomarkers for liver injury in experimental fatty liver disease. PLOS ONE, 9(12), e113651.

[53] Wei, S.; Zhang, M.; Yu, Y.; Xue, H.; Lan, X.; Liu, S. and Hatch Gand Chen, L. (2016): HNF- $4 \alpha$ regulated miR-122 contributes to development of gluconeogenesis and lipid metabolism disorders in Type 2 diabetic mice and in palmitate-treated HepG2 cells. Eur J Pharmacol, 791, 254-263.

[54] Rosen, E. D. and Spiegelman, B. M. (2006): Adipocytes as regulators of energy balance and glucose homeostasis. Nature, 444(7121), 847-853. 
[55] Kopelman, P. G. (2000): Obesity as a medical problem. Nature, 404(6778), 635-643.

[56] Tang, Y. F.; Zhang, Y.; Li, X.Y.; Li, C.; Tian, W. and Liu, L. (2009): Expression of $\mathrm{miR}-31$, miR-125b-5p, and miR-326 in the adipogenic differentiation process of adipose-derived stem cells. OMICS, 13(4), 331-336.

\section{الملخص العربي}

توصيف الأحماض النوويه الريبوزيه الميكرو داخل الإكسوزوم ودور هم كمؤشرات حيوية لتثخيص المتلازمه الأيضيه

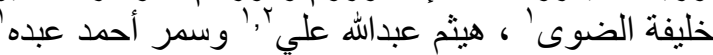

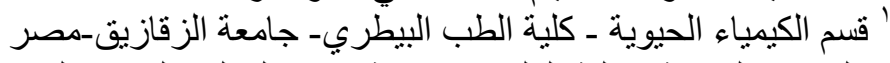

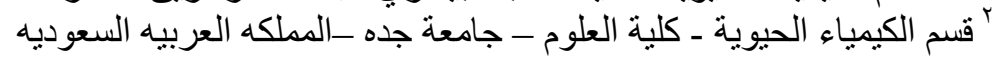

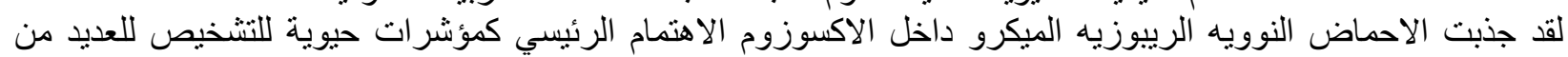

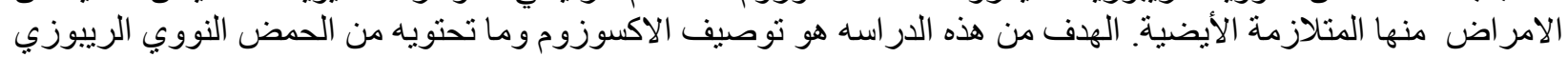

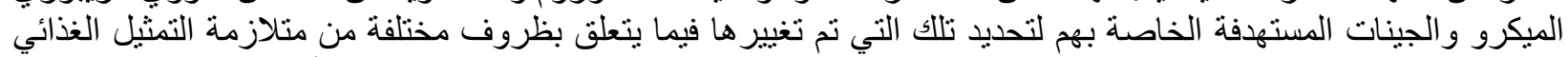

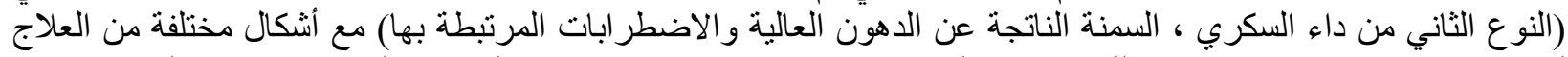

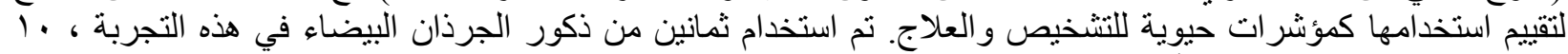

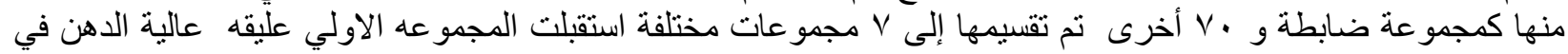

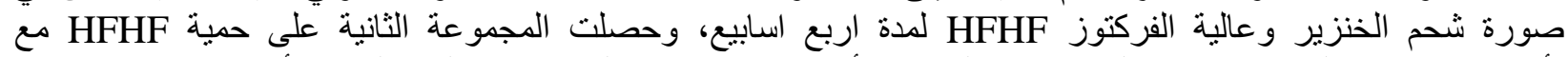

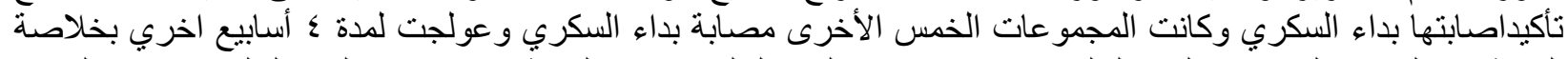

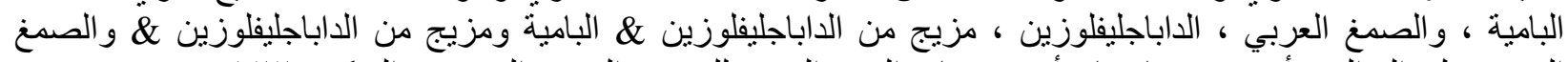

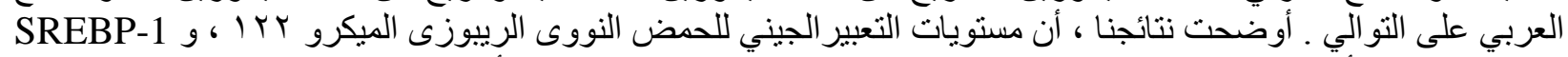

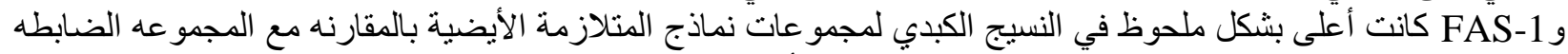

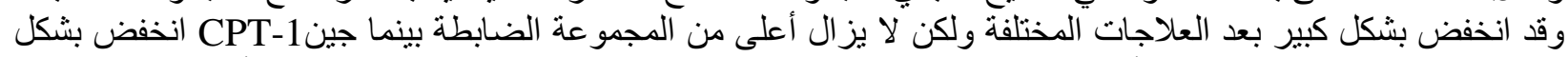

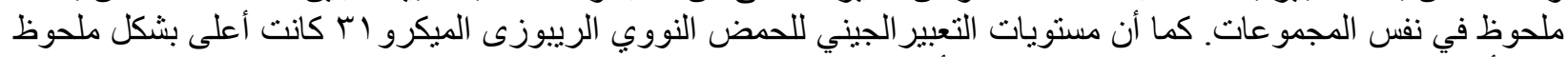

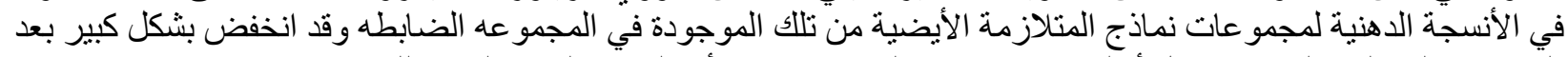

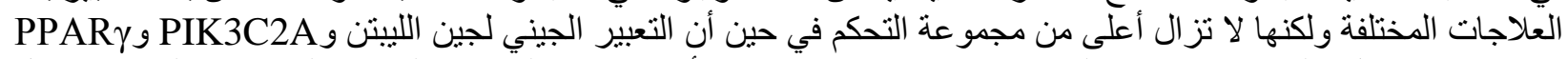

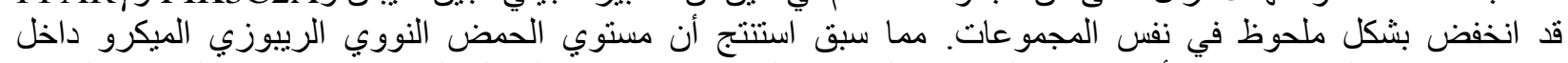

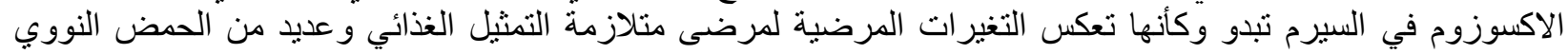

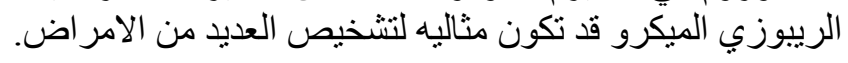

